\title{
THIRTY YEARS IN THE SERVICE OF THE HABSBURGS: INSIGHT INTO THE DEVOTED WORK OF THE TURKISH DRAGOMAN (INTERPRETER) JOHANN ADAM LACHOWITZ $(1678-1709)^{1}$
}

\author{
Hajnalka Tóth
}

Dttp://orcid.org/0000-0003-1913-8096

University of Szeged (Hungary)

\begin{abstract}
The article focuses on the career and activities of Johann Adam Lachowitz. In December 1707, the Commander of Pétervárad (present day Петроварадин (Petrovaradin) in Serbia) nominated him as the head of a committee which met with the Ottoman commissaries on the border between the Habsburg and the Ottoman Empire. The committee was created to negotiate in the case of 55 Muslim and Greek merchants who were murdered in Kecskemét on April 3, 1707. The negotiations took almost one and a half years and were his last completed assignment. He died a few months later, just after the consensus was reached in May 1709. Lachowitz did not have a violent death, but one can assume that the deplorable living conditions he had to endure his whole life, might have largely contributed to his indisposition and subsequent death. This paper shall provide an insight into these living conditions. The research on the career of the Turkish interpreter, later the chief

1 This paper was written with the support of the János Bolyai Research Scholarship (Temesvári Oszmán aga diplomáciai tevékenysége a 17-18. század fordulóján a Habsburg-oszmán határvidéken, 2016-2019). The research related to this paper was supported by the Austrian-Hungarian Action Foundation (Osztrák-Magyar Akció Alapítvány) and by the Ministry of Human Capacities (Emberi Erőforrások Minisztériuma) through the grant (code no. 20391-3/2018/FEKUSTRAT). This paper is written as a contribution of the Interdisciplinary Centre of Excellence, the Department of Medieval and Early Modern Hungarian History (Faculty of Humanities and Social Sciences) (University of Szeged), and the MTASZTE Research Group of the Ottoman Age. In addition, I owe a debt of gratitude to András Oross, the delegate of the Hungarian Archives in Vienna, for his selfless assistance provided during the research.

(Temesvár present day is Timişoara in Romania. - H.T.)

This article has already been published in part in Hungarian. The current paper is an enlarged, revised and, as well, updated version of the earlier published study. See the earlier article in Hungarian: H. Tóth, "Harminc év Habsburg-szolgálatban: Betekintés Johann Adam Lachowitz török tolmács áldozatos munkájába (1678-1709)," Fons 2019, no. 1, pp. 39-62.
\end{abstract}


interpreter and then the secretary, can further enrich the academic narratives about the lives, services and office advancements of the lower officials in the Habsburg diplomatic organization. The interpreters (in the presented case, the interpreters of Oriental languages (dragomen)) assisted both courts with their services, which were arduous and often required personal sacrifices. They were the backbone of all the diplomatic structures in the Sublime Porte, in Vienna and on the Habsburg-Ottoman border as well. The outbreak of conflicts, the process of peace making and the corroboration of peace treaties were dependant on their contributions. Even though they were not soldiers, they nevertheless risked their lives while serving in an especially influential part of the Habsburg state structure.

Keywords: Johann Adam Lachowitz, Habsburg Interpreter, Dragoman, Interpreter of Oriental languages, Sprachknabe, Habsburg-Ottoman Diplomacy, Michael Talman.

In December 1707, the Commander of Pétervárad, Dietrich Heinrich von Nehem, nominated the secretary Johann Adam Lachowitz, interpreter (or dragoman (Ger. Dolmetscher) of Oriental languages, to head the board of enquiry that had to meet with the Ottoman commissioners at Szalánkemén (present day Стари Сланкамен (Stari Slankamen) in Serbia) on the frontier of the Habsburg Monarchy and the Ottoman Empire. The creation of the two boards of enquiry became necessary primarily due to the strike made by Serbian military elements against Kecskemét on April 3, 1707 and the consequences of this. The Serbian Hajdús (Heyducks) and Hussars who were in Habsburg service at this time did not only devastate the city that was in the hand of Kurucs, but also killed 55 Muslim and Greek merchants who were there, even though they had a safe-conduct (salvus conductus) issued by the Commander of Szeged, Johann Friedrich von Globitz. ${ }^{2}$

Michael Talman, the Habsburg resident (permanent envoy; in the following: resident) in Constantinople at that time, ${ }^{3}$ made a recommendation to the Ottoman leadership in accordance to the orders he received. In this, he stated that both sides appoint special commissioners in the manner set down in the Treaty of Karlowitz who would clarify the disputed issues arising in the matter at the site, on the frontier. ${ }^{4}$ The aforementioned Commander of Pétervárad, Nehem was assigned to lead the negotiations

2 For more details about the events at Kecskemét, see: H. T ó t h, "Török kereskedők nehézségei a kuruc korban - avagy hogy ne kereskedjünk Magyarországon a Rákóczi-szabadságharc idején,” Acta Historica 2018, pp. 87-106.

3 For information on Michael Talman, see: D. Kerekes, “A császári tolmácsok a magyarországi visszafoglaló háborúban," Századok 2004, no. 5, pp. 1226-1227; J. Szabados, "Michael Talman Konstantinápolyi Habsburg rezidens két jelentése az Udvari Haditanács részére (1705. július 25. és augusztus 13.)," Fons 2013, no. 3, pp. 385-386; idem, "Hírek Konstantinápolyból 1705 derekán. A nagypolitika történései egy Habsburg diplomata szemüvegén keresztül," Hadtörténelmi Közlemények 2015, no. 1, p. 76.

4 Article 11 of the Treaty of Karlowitz declares that appointed commissions must attempt to resolve all disputed issues and differences of opinion that endanger the peace on the frontier. L. Szita, G. Seewann, A karlócai béke és Európa. Dokumentumok a karlócai béke történetéhez 1698/1699, Pécs 1999, p. 219; Zwischen Paschas und Generälen. Bericht des 'Osman Ağa aus Temeschwar über die 
on the Habsburg side sometime in September 1707, and on the Ottoman side, the matter was placed under the authority of the Governor of Belgrade, Elçi İbrahim Pasha. İbrahim Pasha was able to appoint the members of the negotiation committee by December 1707.5 All of them, as well as Johann Adam Lachowitz - accompanied by lieutenant colonel Caspar Dörck and an aide, named Haas - received commissions to resolve a quite delicate frontier conflict. ${ }^{6}$

The Habsburg negotiator, Johann Adam Lachowitz, stands at the centre of the present essay, and his negotiation of the Kecskemét affair was the final commission he completed, since he lost his life under unfortunate circumstances in July 1709. It is particularly valuable that in spite of the scanty source data, it is possible to gain a glimpse of the life, activities and opportunities for advancement of a man serving at the lower levels of the Habsburg administrative system. The outline of his career that emerges draws attention to the fact that through the many sacrifices they made during their service, Lachowitz and his colleagues contributed to a significant extent to the functioning of the diplomatic systems of the Sublime Porte, Viennese Court and the Habsburg (Hungarian)-Ottoman frontier through the settling of conflicts between the two empires and the signing of treaties. ${ }^{7}$

Höhepunkte seines Wirkens als Diwansdolmetscher und Diplomat, eds. F. Kornauth, R.F. Kreutel, Graz-Wien-Köln 1966, p. 64.

5 For the members of the Ottoman commission, see: Der Gefangene der Giauren. Die abenteuerlichen Schicksale des Dolmetschers Osman Ağa aus Temescwar, von ihm selbst erzählt, eds. R.F. Kreutel, O. Spies, Graz-Wien-Köln 1962, p. 207; Zwischen Paschas, p. 65. Elçi İbrahim, the Pasha of Belgrade to General Dietrich Nehem. Belgrade, December 10, 1707. Österreichisches Staatsarchiv (in the following: ÖStA) Haus-, Hof- und Staatsarchiv Staatenabteilungen (in the following: HHStA) Türkei I. Kt. 177. Konv. 3. fol. 214r.

6 Dietrich Nehem to the Aulic War Council (Wiener Hofkriegsrat), Pétervárad, December 12, 1707. ÖStA HHStA Türkei I. Kt. 177. Konv. 3. fol. 216r. Cf. Dietrich Nehem to Michael Talman, Pétervárad, December 16, 1707. Ibidem, fol. 219r. In Osman Agha's memoirs, the imperial commissioners were Lackowitz (chief interpreter of the Aulic War Council), Türckh (engineer, lieutenant colonel of Pétervárad) and Kastner (captain of the general's bodyguard regiment). Der Gefangene, p. 207; Zwischen Paschas, pp. 65-66.

7 The quite abundant international literature dealing with the lives of the envoys, translators, spies and chiauses in the service of the Habsburgs or the Sublime Porte, is now supplemented with new Hungarian works. With no attempt at being comprehensive, for further reading, a non-exhaustive list of Hungarian literature, see: P. Ács, "Bécsi és magyar renegátok mint szultáni tolmácsok: Mahmud és Murád" [in:] Tanulmányok Szakály Ferenc emlékére, eds. P. Fodor, G. Pálffy, I.Gy. Tóth, Budapest 2002, pp. 1527; Zs. Cziráki, "Zur Person und Erwähnung des kaiserlichen Residenten in Konstantinopel, Simon Reniger von Renningen (1649-1666)" [in:] Wiener Archivforschungen: Festschrift für den ungarischen Archivdelegierten in Wien, István Fazekas, eds. Zs. Cziráki et al., Wien 2014, pp. 157-164; idem, "Habsburg-oszmán diplomácia a 17. század közepén: Simon Reniger konstantinápolyi Habsburg rezidens kinevezésének tanúságai (1647-1649)," Századok 2015, no. 4, pp. 835-871; G. Kármán, Egy közép-európai odüsszeia a 17. században. Harsányi Nagy Jakab élete, Budapest 2013; idem, "Zülfikár aga portai fötolmács," Aetas 2016, no. 3, pp. 54-76; D. Kerekes, "Johann Christoph von Kindsberg konstantinápolyi császári követ hagyatéka 1678-ból," Lymbus 2003, pp. 151-179; idem, “A császári tolmácsok;" idem, "Egy császári tolmács megfigyelései. Giorgio Cleronome magyarországi utazása 1664ben," Lymbus 2004, pp. 71-77; idem, "Frakcióharcok Bécsben a XVII. század végén," Lymbus 2008, pp. 163-191; idem, Diplomaták és kémek Konstantinápolyban, Budapest 2010; idem, “Az első „Keleti Nyelvek Kollégiuma” Bécsben. A császári tolmácsok képzése a 17. század végén” [in:] Österreichisch- 


\section{THE BEGINNINGS}

In December 1709, Polixenia Catharina von Lachowitz, Johann Adam Lachowitz's widow, cited the thirty years of loyal service her deceased husband had shown towards the Habsburg court in her petition submitted to the Aulic War Council (Wiener Hofkriegsrat) for an annuity. ${ }^{8}$ That is to say, Lachowitz's appearance in the official Habsburg system took place in the 1670s, but there is little information about the beginning of his career. In any case, he is found alongside Bartholomeus Huber and Heinrich Christoph Schwegler amongst the first students at the Seminar for Oriental Languages (Seminar für Orientalische Sprachen) founded in 1674 in Vienna by the Chief interpreter of Oriental languages, Johann Baptist Podestà. ${ }^{9}$ The Seminar was created with the intention of teaching eastern languages to talented children, who would then be sent to Constantinople. There, they would be able to perfect their linguistic abilities alongside the envoy, and thereby ensure the supply of Sprachknabes (apprentice translators and interpreter), translators and envoys. We know on the basis of Podestà's account that Lachowitz has been studying at the institute for four years, until $1678,{ }^{10}$ when he was able to go to Constantinople together with his teacher and fellow students accompanying the imperial internuncio (envoy extraordinary) Peter Franz Hoffmann von Ankerskron. ${ }^{11}$ Already in November of that year, Lachowitz had

ungarische Beziehungen auf dem Gebiet des Hochschulwesens, eds. Zs.K. Lengyel, J.Zs. Nagy, G. Új váry, Székesfehérvár-Budapest 2010, pp. 93-106; Á. Kovács, "Habsburg-oszmán diplomácia a harmincéves háború utolsó éveiben: Alexander Greiffenklau von Vollrats rezidensi tevékenysége" [in:] Paletta. II. koraújkor-történeti tudományos diákkonferencia, eds. D. Bódai, B. Vida, Volume of Essays, Budapest 2015, pp. 93-111; S. Papp, "Egy Habsburg-követ, Simon Reniger oszmán kapcsolathálózata Konstantinápolyban. Vezírek, muftik, magyar renegátok," Aetas 2016, no. 3, pp. 40-53; idem, "A Képes Krónika, Thuróczy János krónikája és a Tárih-i Üngürüsz kapcsolata. Volt-e „török fogságban” a Képes Krónika?" [in:] Szent Márton és Benedek nyomában. Tanulmányok Koszta László emlékére, Fontes et Libri 3, eds. T. Fedeles Tamás, Zs. Hunyadi, Szeged-Debrecen 2019, pp. 342-357; J. Szabados, “A 17. századi Habsburg-hírszerzés „gyöngyszeme”. Hans Caspar budai titkos levelező (1646-1659) munkássága. Vázlat egy nagyobb összefoglaláshoz," Aetas 2016, no. 3, pp. 77-92; idem, "Habsburgoszmán kommunikáció a 17. század derekán. Johann Dietz császári futár halálának körülményei és következményei" [in:] Szóra birni az újkort. A III. KoraújkorÁSZ doktorandusz konferencia tanulmányai, eds. T. Bodnár-Király, F. Hende, K. Pataki, Budapest 2016, pp. 192-216; ibidem, ,Ih awer befleise mih, daß ih sie beidte zue nahbarn mahen khan." - Die Karriere des deutschen Renegaten (Hans Caspar) in Ofen (1627-1660) im politischen und kulturellen Kontext, PhD dissertation, Doctoral School of History, Faculty of Humanities and Social Sciences, University of Szeged, Szeged 2018 (doktori.bibl.u-szeged. hu/10058/1/Disszertáció_I kötet_Szabados János.pdf [accessed: February 7, 2018]).

8 ÖStA Finanz- und Hofkammerarchiv Hoffinanz Ungarn (in the following: FHKA HFU), Akten 24. September 1709. Kt. 1024. fol. 342.

9 D. Kerekes, Diplomaták, p. 89. The Seminar was established on the basis of a command by Leopold I (1657-1705), the King of Hungary and Holy Roman Emperor, on October 18, 1674. For more on the institute, see: D. Kerekes, Az elsö „Keleti Nyelvek Kollégiuma”, pp. 93-106.

10 D. Kerekes, Diplomaták, p. 91; D. Kerekes, Az első „Keleti Nyelvek Kollégiuma”, p. 103, p. 103 , note 40 .

11 ÖStA Kriegsarchiv, Hofkriegsrat Protocollbücher (in the following: KA HKR Prot.) Bd. 354. Registratur (in the following: Reg.) (1678) fol. 104. (March 7, 1678). Johann Peter Hoffmann von 
petitioned the Aulic War Council to employ him as the resident's assistant. ${ }^{12}$ Then, according to a notation in the registry of the War Council from the autumn of 1679, Lachowitz's mother submitted a petition in relation to having her son employed as a Sprachknabe, and for the proper pay to be given to him. ${ }^{13}$ Presently we do not have any more direct information about the role of his mother, but based on the petition it can be rightfully presumed that she may have been well versed in the official world of the court since she wanted to promote the career of her son this resolutely. The petition achieved its objective, since the Aulic War Council - according to its order of October 30, 1679 - asked to allocate 50 Rhenish guilders for Sprachknabe Lachowitz for supporting his studies and for his living expenses. ${ }^{14}$ So, the apprentice, who was presumably quite young, was allowed to stay abroad at the Sublime Porte to improve his language skills and to obtain personal experience in the eastern world.

At the same time, the registries also attest that while Lachowitz was already due the pay given to a Sprachknabe, in April 1680, Podestà still requested that the Aulic War Council in attendance (hinterlassener Hofkriegsrat, viz operating alongside the Emperor) pay the annual allowance for his three students, besides this the approved money for Lachowitz too. ${ }^{15}$ According to the entries, the official machinery was operating quite actively. On April 16, the Aulic War Council in attendance had already written on this matter to the resident in Constantinople, Georg Christoph von Kunitz - who had arrived at Küçükçekmece near the capital on March 23, 1680, where the Habsburg translators and apprentice translators received him $^{16}$ - as well as to the Aulic Chamber (Hofkammer) that Lachowitz should get the 300 Rhenish guilders and the other apprentices, Hueber (Bartholomeus Huber) ${ }^{17}$, Pezely (Chris-

Ankerskron arrived in Constantinople as a Habsburg internuncio in 1678, but since the resident at that time, Johann Kindsberg (resident: 1672-1678) died in December 1678, he had to remain at the Sublime Porte. However, the new resident, Johann Carl Terlingo de Guzmán (resident: 1679-1680) arrived after the death of Hoffmann (September 10, 1679). D. Kerekes, "Frakcióharcok...," p. 185, note 114; D. Kerekes, Diplomaták, p. 150. Cf. B. Spuler, "Die europäische Diplomatie in Konstantinopel bis zum Frieden von Belgrad (1739)," vol. 3, Jahrbücher für Kultur und Geschichte der Slaven 1935, pp. 338-339. In relation to Hoffmann's trip, see: ÖStA KA HKR Prot. Bd. 356. Reg. (1679) fol. 539-540. For the journey of Podestà and his students to Constantinople, see: D. Kerekes, Diplomaták, p. 101. The Italian-Ottoman dictionary that Lachowitz used during his language studies - and perhaps even in Constantinople - has survived. The dictionary, which has his name and the date 1678 inscribed by his own hand on the inside of the cover, currently can be found at the Department of Near Eastern Studies at the University of Vienna (Institut für Orientalistik, Universität Wien).

12 ÖStA KA HKR Prot. Bd. 353. Expedit (in the following: Exp.) (1678) fol. 764. (November 1678).

13 Ibidem, Bd. 355. Exp. (1679) fol. 691r. (October 1679).

14 Ibidem, Bd. 356. Reg. (1679) fol. 540v. (30 October 1679) Cf. ÖStA HHStA Türkei I. Kt.149. Konv. 1. fol. 126r; ibidem, Kt. 150. konv. 1. fol. 137v; D. Kerekes, “A császári tolmácsok,” p. 1221. Lachowitz received his official appointment on April 16, 1680: ÖStA HHStA Türkei I. Kt. 164. Konv. 7. fol. 149v; D. Kerekes, “A császári tolmácsok,” p. 1221.

15 Johann Baptist Podestà to the Aulic War Council in attendance. Vienna, April 1680: ÖStA KA HKR Prot. Bd. 359. Exp. (1680) fol. 247r.

${ }_{16}$ For the life and activity of the resident envoy in Constantinople, Georg Christoph von Kunitz (1680-1683), see: D. Kerekes, Diplomaták, pp. 149-154, 158-171.

17 He fell into Ottoman captivity in May 1688. D. Kerekes, “A császári tolmácsok,” p. 1200. 
tian Esaid Pezelli) ${ }^{18}$ and Schwegler (Heinrich Christoph Schwegler) ${ }^{19}$, should also get 100 Rhenish guilders per capita, that had not been paid each. ${ }^{20}$ In September, the War Council in attendance informed both the left behind (viz. stood in Vienna) War Council and the Aulic Chamber, as well as Kunitz, that the Aulic War Payment Office (Hofkriegszahlamt) had received an order to make the payments. ${ }^{21}$ Then the remaining Aulic War Council (anwesender Hofkriegsrat) requested that the remaining Aulic Chamber send 200 imperial thalers for extra expenses to the interpreter Marc' Antonio Mamucca della Torre ${ }^{22}$ working alongside the resident in Constantinople and that 300 imperial thalers had been ordered to cover his studies. ${ }^{23}$

The name of the Sprachknabe Lachowitz appears in the sources in November 1681, again only due to the payment of overdue allowances, since he reported again to the War Council, and from there the complaint was forwarded to the Aulic Chamber, citing the resolution of April 1680, that had ordered the payment of the 300 Rhenish guilders. We also learn that according to the plans, the money that had not yet been paid out would be brought by the internuncius, Alberto Caprara ${ }^{24}$ to Constantinople. ${ }^{25}$ During all of this, Lachowitz was also striving to move forward in building his career, since at the same time he also submitted a request to fill the position of interpreter left vacant by the death of Giorgio Rudolfi d'Aleppino (Georgen Rudolphi Aleppini). ${ }^{26}$ The Aulic War Council had François (Franz) Mesgnien de Meninski ${ }^{27}$ review his

18 This apprentice translator and translator died at the end of 1683. D. Kerekes, "A császári tolmácsok," p. 1200.

19 D. Kerekes, Diplomaták, p. 95.

20 ÖStA KA HKR Prot. Bd. 360. Reg. (1680) fol. 145r. Cf. ibidem, Bd. 359. Exp. (1680) fol. 496r. The Aulic War Council in attendance to Kunitz, August 14, 1680: ibidem, Bd. 360. Reg. (1680) fol. 339r. The Aulic War Council in attendance to the Aulic Chamber, August 14, 1680: ibidem, fol. 342r.

21 ÖStA KA HKR Prot. Bd. 360. Reg. (1680) fol. 389r.

22 For information on his life and career, see: D. Kerekes, "A császári tolmácsok," pp. 1203-1209; D. Kerekes, Diplomaták, pp. 97-104; D. Kerekes, “Titkosszolgálat volt-e a Habsburgok 16-17. századi „Titkos Levelezői Hálózata”?” [in:] Kémek, ügynökök, besúgók. Az ókortól Mata Hariig. A szombathelyi Mediawave Fesztivál keretében 2011. június 3-án megrendezett tudományos konferencia elöadásai, ed. Cs. Katona, Szombathely 2014, pp. 114-117.

23 ÖStA KA HKR Prot. Bd. 358. Reg. (1679-1680) fol. 410v (September 13, 1680). The money that was sent (a total of 4,000 ducats) was brought by the courier Ciriaco to resident Kunitz. Ibidem, fol. 435 .

${ }^{24}$ The imperial internuncio Alberto Caprara set off on his journey to Constantinople in February 1682, with an entourage of seventy-six people to procure the extension of the Peace of Vasvár of 1664. D. Kerekes, Diplomaták, p. 153; H. Tóth, A Kanizsával szembeni végvidék Gyöngyösi Nagy Ferenc levelezése tükrében (1683-1690), Szeged 2013, p. 58, p. 58, note 299.

${ }_{25}$ Lachowitz to the Aulic War Council in attendance, in November 1681: ÖStA KA HKR Prot. Bd. 361. Exp. (1681) fol. 584r.

26 Lachowitz's petition to the Aulic War Council, in November 1681: ibidem, fol. 609r. D’Aleppini accompanied Johann Peter Hoffmann as the interpreter of the resident to the Sublime Porte Johann Christoph von Kindsberg, but just like Hoffmann, he also died in Constantinople. D. Kerekes, "Frakcióharcok...," p. 175, note 59.

27 François Mesgnien de Meninski (1623-1698), the chief interpreter of Oriental languages, was a member of the War Council from 1686. For his career, see: D. Kerekes, "A császári tolmácsok," pp. 1201-1202; D. Kerekes, Diplomaták, pp. 93-95; K. Torma, A 18. századi végi-19. század elejei európai Hâfez-forditások, PhD dissertation, Doctoral School of Literary Studies, Faculty of Humanities, 
petition, so in other words, the chief interpreter of the court at that time had to declare whether Lachowitz was qualified for the post of interpreter. ${ }^{28}$ Mesgnien provided a reply to the War Council in April 1682, ${ }^{29}$ and although the War Council's record book did not go into detail about the opinion of the chief interpreter, it must have been positive, since on April 28, Lachowitz was informed that he had received Aleppini's position and therefore his salary was also raised to 600 Rhenish guilders per year. ${ }^{30}$

Following this, Lachowitz may have returned to Vienna. In August 1682, the internuncio Alberto Caprara, who was in Constantinople, was informed that Lachowitz had received permission to return to Vienna with his delegation. ${ }^{31}$ The imperturbable operation of the Habsburg bureaucratic machinery indicates that in their orders dated on April 1, 1683, they had also requested Caprara's opinion on whether Lachowitz had perfected his Turkish language skills to such an extent that he would be able to perform the duties of an interpreter at the court - which may have also been due to a lack of confidence or to extraordinary caution by the War Council. ${ }^{32}$ On the way back - now in the camp of the Grand Vizier Kara Mustafa Pasha (1676-1683) - Lachowitz continued to serve alongside the internuncio to Buda and then to Vienna. ${ }^{33}$

Eötvös Loránd University, Budapest 2013, p. 8. (http://doktori.btk.elte.hu/lit/tormakatalin/diss.pdf [accessed: July 5, 2018]). Cf. The General Biographical Dictionary Containing an Historical and Critical Account, ed. A. Chalmers, vol. 22, London 1815, pp. 52-54; Universal Lexikon der Gegenwart und Vergangenheit oder neuestes encyclopädisches Wörterbuch der Wissenschaften, Künste und Gewerbe, ed. H.A. Pierer, Altenburg 1843, pp. 164-165.

28 Meninski to the Aulic War Council in attendance, in November 1681, see: ÖStA KA HKR Prot. Bd. 361. Exp. (1681) fol. 576r.

29 Ibidem, Bd. 364. Exp. (1682) fol. 171v.

30 ÖStA KA HKR Prot. Bd. 365. Reg. (1682) fol. 181v; ÖStA HHStA, Türkei I. Kt. 164. Konv. 7. fol. 169v; D. Kerekes, “A császári tolmácsok,” p. 1222.

31 The Aulic War Council to Alberto Caprara, on August 28, 1682: ÖStA KA HKR Prot. Bd. 365. Reg. (1682) fol. 457. Dóra Kerekes also provided information about Lachowitz's appointment as an interpreter, and she wrote, citing the replacement of the translator of the delegation, Giovanni Benaglia, that in the autumn of 1682 Lachowitz ,travelled with two experienced couriers, Costa and Dane Petrakki" to Constantinople. D. Kerekes, “A császári tolmácsok,” p. 1222. In my opinion that, Benaglia mentioned that Lachowitz had been staying continuously in Constantinople, at Benaglia's house, when he had received his appointment as a translator through the aforementioned couriers. G. Benaglia, Außführliche Reiß-Beschreibung von Wien nach Constantinopel und wieder zurück in Teutschland, auch was sich Merckwürdiges dabey zugetragen: deß Hoch-Gebohrnen Grafen und Herrn, Herrn Albrecht Caprara etc. etc., welche er als Ihro Römisch-Keyserl. Maj. Extraordinari-Gesandter und Gevollmächtigter den Stillstand mit der Ottomannis Pforten zu verlängern, verrichtet, Franckfurt, 1687, p. 90.

32 The Aulic War Council to Alberto Caprara, on April 1, 1683, see: ÖStA KA HKR Prot. Bd. 367. Reg. (1683) fol. 264r.

33 ÖStA FHKA HFU Akten 7. November 1685. Kt. 702. fol. 135r. The orders of the War Council were dated May 21, 1685. Cf. D. Kerekes, “A császári tolmácsok,”p. 1222. 


\section{AT WAR: IN THE SERVICE OF THE EMPEROR}

Lachowitz's return to Vienna did not bring him a calmer life at all. Following the victory won by the Christian troops over the Ottomans on September 12, 1683, at Kahlenberg, he was ordered to accompany the main imperial forces led by Charles V, Duke of Lorraine (1643-1690) as an interpreter, so he found himself at the siege of Esztergom on his first trip. ${ }^{34}$ In the quick succession of events, he probably did not even have time to deal with financial matters. This was not so during the winter season without military activities at the end of 1683 and the beginning of 1684, when he again petitioned for the modification of his salary and the actual issuing of the money. In his petition, he stressed his services performed alongside Caprara during the siege of Esztergom. ${ }^{35}$ The interpreter's raise in salary was finally acknowledged on May 6, 1684, by the Aulic War Payment Office. ${ }^{36}$

In the following period, Lachowitz's activity was defined by the war to end the Ottoman rule over the Carpathian Basin that lasted a decade and a half. The interpreter and his colleagues were dispatched to different theatres of war alongside various imperial forces during the campaigns that were launched year after year, since their language skills and experience were necessary in dealing with the enemy as well as the Ottomans that remained in the conquered or re-conquered castles or those that fell into Christian captivity. During the campaign of 1684, when the main objective was the taking of Buda Castle, Lachowitz was again dispatched as interpreter alongside the main force led by Charles of Lorraine, and he requested the issuance of the money necessary for this and for acquiring the proper equipment in April. ${ }^{37}$ To recognize the results achieved in this year, the War Council initiated the process of raising his salary, although not to the extent that the interpreter had expected. In March 1685, Lachowitz had requested a raise of 300 guilders, ${ }^{38}$ which his former superior in Constantinople, Georg Christoph Kunitz also supported as a member of the War Council. ${ }^{39}$ Then, after appearing before the War Council in April 1685, for

34 The Aulic War Council to Charles of Lorraine, on September 18, 1683, see: ÖStA KA HKR Prot. Bd. 367. Reg. (1683) fol. 539r; ÖStA FHKA HFU Akten 7. November 1685. Kt. 702. fol. 135r. Charles of Lorraine wrote on the matter of Lachowitz's journey to the Aulic War Council, which also informed the Aulic Chamber on the same day. ÖStA KA HKR Prot. Bd. 366. Exp. (1683) fol. 560v.

35 ÖStA FHKA HFU Akten 18. April 1685. Kt. 695. fol. 292. The Aulic War Council initiated the increase in Lachowitz's salary at the Aulic Chamber on January 24, 1684, in other words that he receives 750 guilders instead of the 600 guilders he had up to that point. Ibidem, fol. 284.

36 ÖStA FHKA HFU Akten 4. April 1685. Kt. 695. fol. 295-296. Cf. Lachowitz to the Aulic War Council on the issuance of supplementary pay, May 5, 1684, see: ÖStA KA HKR Prot. Bd. 368. Exp. (1684) fol. 214v.

37 ÖStA KA HKR Prot. Bd. 368. Exp. (1684) fol. 170r, 176v; The Aulic War Council to Lachowitz, on May 31 1684, see: ibidem, Bd. 369. Reg. (1684) fol. 370r.

38 ÖStA KA HKR Prot. Bd. 370. Exp. (1685) fol. 112r, 143v. For his services in 1684 outside Buda, see: ÖStA FHKA HFU Akten 7. November 1685. Kt. 702. fol. 135r.

39 Georg Christoph Kunitz to the Aulic War Council on May 1685, see: ÖStA KA HKR Prot. Bd. 370. Exp. (1685) fol. 291. 
the payment of his overdue salary, ${ }^{40}$ they determined to give him a raise of 150 guilders, so according to the orders of the War Council of May 21, 1685, his annual pay became 900 guilders ${ }^{41}$ His ambitions are clearly reflected by the fact that already in November 1685, he had indicated to the War Council that he was expecting to be appointed the Chief interpreter. ${ }^{42}$

However, many years passed before this happened. In 1686 Lachowitz was again ordered to the main imperial army as interpreter alongside Joseph (Giuseppe) d'Azzaria. ${ }^{43}$ In Árpád Károlyi's monograph on the recapture of Buda and Pest he mentioned a minor interlude that also showed the risk involved in the tasks performed by the interpreters. After the Christians scored a victory over advance troops sent by the Grand Vizier Sarı Süleyman Pasha (1685-1687) on August 14, during the final phase of the siege, Charles of Lorraine sent his adjutant general, count Johann Wilhelm Lamberg, with the Lachowitz to the breach in the castle to negotiate, to call upon Abdurrahman, the Pasha of Buda (1684-1686) to send out a few officers to them, who would be informed of the events by the captive Ottoman officers. However, the pasha greeted them with gunfire, and according to Károlyi's sources, the horse was shot out from under the interpreter. ${ }^{44}$ Currently there is no more immediate information about whether Lachowitz was injured or how he took the incident, but it cannot be a coincidence that at the end of the year he took a portion of the Ottoman prisoners that had been captured at Buda to Györ and to Vienna. ${ }^{45}$ In fact, the War

40 ÖStA KA HKR Prot. Bd. 370. Exp. (1685) fol. 181v.

${ }_{41}$ ÖStA FHKA HFU Akten 7. November 1685. Kt. 702. fol.135r. Cf. ÖStA KA HKR Prot. Bd. 371. Reg. (1685) fol. 262v.

42 ÖStA KA HKR Prot. Bd. 370. Exp. (1685) fol. 531v. For the significance and duties of the imperial chief interpreter, see: I. Hiller, “A „Titkos Levelezők” intézménye” [in:] R. Várkonyi Ágnes Emlékkönyv, ed. P. Tu sor, Budapest 1998, p. 208; D. Kerekes, “A császári tolmácsok,” pp. 1199-1202; D. Kerekes, Diplomaták, p. 93; D. Kerekes, Titkosszolgálat, p. 126.

43 On April 29, 1686, the Aulic War Council informed the Lieutenant General and Chief Paymaster Rudolph von Rabatta (1640-1689) about the Turkish interpreters that had been ordered to the main army. At that time, the names Pandaleon Cleronome and Gollocin appeared alongside Lachowitz's. See: ÖStA KA HKR Prot. Bd. 373. Reg. (1686) fol. 120r. Then on the list sent by the staff on May 9, there were only the names of Lachowitz and Cleronome, see: ibidem, fol. 132r. György Bánrévy mentioned d'Azzaria and Lachowitz in his essay on the first measures taken following the recapture of Buda, and according to this d'Azzaria was appointed to replace Lachowitz as the Turkish interpreter at Buda, and Lachowitz disappeared from the registries of the War Council. Gy. Bánrévy, "Az első intézkedések a visszafoglalt Budán 1686-ban,” Tanulmányok Budapest múltjából 1936, no. 5, p. 261, 267, note 58. Cf. D. Kerekes, "A császári tolmácsok," p. 1225, where the author writes that in the end d'Azzaria was not ordered to Buda. Despite this, he may have been there earlier, as the above sources indicate.

44 Á. Károlyi, Buda és Pest visszavivása 1686-ban, Budapest 1886, pp. 374-375. For the events, see: Lotharingiai Károly hadinaplója Buda visszafoglalásáról, at press, trans. by K. Mollay, Budapest 1686, pp. 172-177. Cf. ibidem, p. 156.

45 Melchior Leopold von der Beck to the Aulic War Council, on December 11, 1686, see: ÖStA KA HKR Prot. Bd. 372. Exp. (1686) fol. 538r. Heinrich Christoph Schwegler reported in January 1687 that Lachowitz had arrived in Györ with the tanner that made Morocco leather, see: ibidem, Bd. 374. Exp. (1687) fol. 43r. Von Beck also mentioned the prisoners in a letter to the War Council in June 1688, see: ibidem, Bd. 376/1. Exp. (1688) fol. 426r. Cf. von der Beck to the Aulic War Council, on November 13, 1686, see: ibidem, Bd. 372. Exp. (1686) fol. 490r. 
Council stated specifically in its order sent on November 18, to the Commander of Buda, Melchior Leopold von der Beck, ${ }^{46}$ that Lachowitz must be kept from having a breakdown. In other words, he was taken from the combat zone and d'Azzaria took over his position. ${ }^{47}$

In accordance with the orders of the Aulic War Council, Lachowitz assembled the list, or lists, of Ottoman prisoners taken captive outside Buda and those still staying in Buda, which Beck also mentioned in his report sent to Vienna on the $13^{\text {th }}$ of November. In addition, he also stated that many of the captives had become ill, and he had already sent them to Györ. ${ }^{48}$ The possibility arose that the captives would be exchanged for Christian prisoners that were still in Ottoman hands from the castles of Eger and Székesfehérvár. ${ }^{49}$ Later, Commander Beck sent two captured miners (Minier) and a tanner with Lachowitz to Vienna. ${ }^{50}$ However, the respite for the interpreter did not last long, since in May 1687, he was appointed again interpreter for the main army, together with d'Azzaria and a former pupil of Podestà, Heinrich Christoph Schwegler. ${ }^{51}$ However, we do not currently have more detailed information about Lachowitz's activity in this year.

46 On the person of Melchior Leopold von der Beck, see: Des Heil. Röm. Reichs GenealogischHistorisches Adelslexicon, ed. J.F. Gauhen, Leipzig 1740, pp. 85-86.

47 ÖStA KA HKR Prot. Bd. 373. Reg. (1686) fol. 424r.

48 Melchior Leopold von der Beck to the Aulic War Council, on November 6, 1686, see: ibidem, Bd. 372. Exp. (1686) fol. 481r. See also Leopold von der Beck to the Aulic War Council, on November 13, 1686: ibidem, fol. 490r. Cf. Gy. Bánrévy, "Az első intézkedések," p. 250, 261. For the lists made of prisoners of war taken at Buda in 1686 and the statements and fates of the captives, see most recently: E. Géra, "Pillanatképek az ostrom utáni Budáról: török hadifoglyok, kincskeresők, szerencsevadászok," Fons 2016, no. 2, pp. 147-206. Cf. J. Herczog, “A Budán és Pesten fogságban lévő törökökről 1686. okt. 25-én készült jegyzék (1686),” Hadtörténelmi Közlemények 1916, pp. 434-435; “A budai várban őrzött török rabok jegyzéke. 1686. október 25” [in:] Buda visszafoglalásának emlékezete, ed. F. Szakály, Budapest 1986, pp. 575-576.

49 Melchior Leopold von der Beck to the Aulic War Council, on November 6, 1686, see: ÖStA KA HKR Prot. Bd. 372. Exp. (1686) fol. 479v. The majority of the Ottomans had become sick and that they would be able to send about 18 janissaries to Székesfehérvár to exchange for the same number of German captives, see: ibidem, fol. 481r. On December 10, 1686, Beck reported how many Ottomans had been sent to Györ and how many had died. He hoped that the two lists taken by Lachowitz had already arrived in Vienna, see: ibidem, fol. 490r. The lists were still not in Vienna on December 19. On this, see the War Council's response to Beck: ibidem, Bd. 373. Reg. (1686) fol. 489.

50 Melchior Leopold von der Beck to the Aulic War Council, on December 11, 1686, see: Ibidem, Bd. 372. Exp. (1686) fol. 538r. Heinrich Christoph Schwegler reported in January 1687, to the War Council that Lachowitz had arrived in Györ with the tanner that made Morocco leather, see: ibidem, Bd. 374. Exp. (1687) fol. 43. Melchior Leopold von der to the Aulic Council, in June 1688, see: ibidem, Bd. 376/1. Exp. (1688) fol. 426r.

51 The order of the Aulic War Council on the military staff, on May 5, 1687, see: Ibidem, Bd. 375. Reg. (1687) fol. 253r. 


\section{THE HABSBURG INTERPRETER AT THE PEACE NEGOTIATIONS}

The year 1688 represented a turning point in both the course of the war against the Ottomans and in the life of the interpreter Lachowitz. The pace of the war halted after the army of Louis XIV, King of France (r. 1643-1715) invaded the territory of the Palatinate, thereby drawing away a significant portion of the Habsburg forces from the Hungarian theatre of war. At the same time, the Ottoman side made an overture to commence peace negotiations to gain some time due to the significant losses it had suffered since the outbreak of the war. Envoys from the Sublime Porte were sent to the imperial capital including Zülfikar Efendi ${ }^{52}$ and the chief interpreter Alexandro Mavrocordato, ${ }^{53}$ as well as Tommaso Tarsia, ${ }^{54}$ the chief interpreter of Venice at the Sublime Porte. The delegation that included an entourage of nearly 100 people arrived in Belgrade in September 1688, then in Pottendorf on October 13, where they were given accommodations, and the interpreter Lachowitz escorted them to the imperial court. It is possible to read about the journey of the delegation from Belgrade to Pottendorf, the events that took place in the meantime and the ceremonial audience with the Emperor in Lachowitz's report of February 8, 1689. ${ }^{55}$ The audience with the emperor took place on February 8, 1689, ${ }^{56}$ but by that time the imperial response to the Ottoman offer was already ready. ${ }^{57}$ In February, Lachowitz made a report from alongside the Ottoman delegation staying in Pottendorf on the basis of the accounts of the members of the delegation about the journey of the Habsburg delegation that had arrived at the Sublime Porte as well as the ceremony that took place at the audience before the Sultan. ${ }^{58}$

52 For a manuscript made on Zülfikar Efendi's negotiations in Vienna in 1688-1689, see: Zülfikar mükalemesi. Vienna, Österreichische Nationalbibliothek, H.O.90. Cf. M.F. Molnár, Az Oszmán és a Habsburg Birodalom közötti határ kijelölése a karlócai békét követöen (1699-1701), PhD dissertation, Doctoral School of History, Faculty of Humanities, Eötvös Loránd University, Budapest 2008, p. 45, note 103. (Page numbers according to the pdf document, see: http://doktori.btk.elte.hu/hist/fmolnar/ phdmolnar.pdf [accessed: August 18, 2018].)

53 The chief interpreter of the Sublime Porte Alessandro Maurocordato (1673-1709). Biografia universale antica e moderna, vol. 36, Venezia 1827, pp. 367-368.

54 For information on him, see: E.N. Rothman, Between Venice and Istanbul. Trans-Imperial Subjects and Cultural Mediation in The Early Modern Mediterranean. PhD dissertation, University of Michigan, Ann Arbor 2006, p. 240, 247, 338, https://utsc.utoronto.ca/ rothman/RothmanDiss.pdf [accessed: August 10, 2018]); D. Kerekes, "Frakcióharcok...," p. 181, note 93.

55 ÖStA HHStA Türkei I. Kt. 153. Konv. 3. fol. 41-49. (with his own hand); ibidem, Kt. 154. Konv. 1. fol. 57-64. (copy); L. Szita, G. Seewann, A karlócai béke, pp. 27-32.

56 Lachowitz received orders on January 12,1689 , to accompany the delegation to the audience with the Emperor, where they considered the presence of the interpreter necessary in addition to the head translator, Meninski, who was present. See: ÖStA HHStA Türkei 1. Kt. 153. Konv. 4. fol. 97r. The response provided to the imperial instructions and the requests of the Ottoman delegation can be read in Lachowitz's report of January 16, 1689, see: ibidem, fol. 110-117.

${ }^{57}$ L. Szita, G. Seew ann, A karlócai béke, pp. XXIX-XXX., pp. 10-16.; F. Molnár, Az Oszmán, p. 4.

58 ÖStA HHStA Türkei I. Kt 153. fol. 166-170; L. Szita, G. Seew ann, A karlócai béke, pp. 23-25. Cf. the order of the Aulic War Council of November 5, 1688, about Lachowitz needing to continue to perform his duties alongside the Ottoman internuncio, see: ÖStA KA HKR Prot. Bd. 377. Reg. (1688) fol. 
Information is found about the work of the interpreter with the Ottoman delegation from his reports sent to the Aulic War Council and their brief abridged versions. For example, in April 1689, he informed the War Council that he was able to obtain useful and reliable information about the members of the delegation through confidential conversations. ${ }^{59}$ Also in April, he corresponded in the matter of a Turk by the name of Süleiman who had escaped from the quartermaster of Györ, ${ }^{60}$ and in June he forwarded to the court the translation of an Ottoman-Turkish language letter that had been sent from Buda to Zülfikar Efendi. ${ }^{61}$ In December, the Aulic War Council in attendance with the Emperor requested that the remaining Aulic Chamber pay 24 Rhenish guilders to Ádám Baráth, the director of the commissariat in Györ, through Lachowitz, since the Ottoman delegation owed him. ${ }^{62}$ In January 1690, Lachowitz turned to the War Council with the request that they give permission to the Ottoman chief interpreter, Mavrocordato, to purchase eight pairs of pistols for his men, and that Zülfikar Efendi be allowed to purchase six special sets of shears for the barber. The War Council granted the petition, but they were not allowed to go beyond the amount mentioned above. ${ }^{63}$ Emperor Leopold ordered 900 Rhenish guilders to be sent to Lachowitz as interpreter and escort for the work he had performed between September 5, 1688 and February 6, 1689. ${ }^{64}$ Then in April 1690, the interpreter requested passports for two Serbs, one of whom wanted to go to Belgrade and the other one to Vienna. ${ }^{65}$ Then, in May he again sent a list from the Sublime Porte to the War Council about the documents sent to the Ottoman delegation that was staying (or rather had been detained) in Komárom. ${ }^{66}$

In August 1691, Lachowitz, perhaps inspired by the tasks he had performed in the preceding years, although certainly also due to Meninski's serious sickness, made a petition to be given the rank of imperial chief interpreter, ${ }^{67}$ which however he did not receive at this time. Presently, we only have quite sporadic information about him from the following years. He was presumably living in Vienna and may have

517r. Cf. Polixenia Catharina von Lachowitz's petition submitted for an annuity: ÖStA FHKA Hoffinanz Österreich (HFÖ) Akten 12. Dezember 1710. Kt. 1902.

59 ÖStA KA HKR Prot. Bd. 378. Exp. (1689) fol. 203v.

60 Ibidem, fol. 252r.

${ }^{61}$ Ibidem, fol. 379v. On November 20, the three letters that Hasan Agha had taken to Zülfikar Efendi and Lachowitz were sent on by the remaining Aulic War Council to the Aulic War Council in attendance, see: ibidem, Bd. 382. Reg. (1689) fol. 147v.

62 Ibidem, fol. 203r.

63 Ibidem, Bd. 380. Exp. (1689-1690) fol. 270v-271r.

64 ÖStA FHKA HFÖ Akten 30. Oktober 1705. Kt. 1764. In 1689, when the translator Heinrich Schwegler who had served in the blockade of Kanizsa appealed to the War Council for pay beyond his normal allowance due to the increased expenses, he cited Lachowitz, whose extra expenses they had refunded and paid him 6 guilders daily. D. Kerekes, Diplomaták, pp. 96-97.

65 ÖStA KA HKR Prot. Bd. 384. Reg. (1690) fol. 114v.

${ }_{66}$ Ibidem, fol. 214v. For the detainment of the delegation, see the protests and complaints of the envoys dated July 4, 1690, in Komárom. See: L. Szita, G. Seewann, A karlócai béke, pp. 34-38. Lachowitz translated into German the copy of this which was sent to the Emperor, see: ÖStA HHStA Türkei I. Kt. 154. fol. 134-138.

${ }^{67}$ ÖStA KA HKR Prot. Bd. 385. Exp. (1691) fol. 460r. Podestà also applied for the office. 
been ordered to accompany minor Ottoman delegations as an interpreter. From these years, his name primarily appears in the sources in connection with complaints due to defaults in sending pay to him and his compatriots. In January 1692, he wrote to the War Council because two Ottomans captured at Neustadt wanted to speak with him about their ransom. ${ }^{68}$ At this time, the War Council had not yet decided on his further duties, ${ }^{69}$ but a bit later they had sent him along with Wolfgang Joseph Kreutz Generalwachtmeister to accompany a minor Ottoman delegation that had arrived in Pottendorf, and at this time he turned to the Chamber through the War Council for his expenses to be paid. ${ }^{70}$ In April, Lachowitz himself requested instructions in connection with the Ottoman delegation that was leaving, and asked about his new duties. ${ }^{71}$ Despite receiving a response to his letter from the Aulic War Council on April 22, it is not clear where they ordered him from the surviving brief entry. ${ }^{72}$ During his work, alongside the Ottoman delegation, 103 Rhenish guilders were allocated to him as $k s l$. hoff- und veldt dolmetschen (viz. 'imperial court and military interpreter'). ${ }^{73}$ More than a year later, in the autumn of 1693, Lachowitz was still complaining to the Aulic Chamber that he still was not able to get the Aulic War Council to send him his payment. ${ }^{74}$ According to evidence from the documents, neither the interpreters nor those working alongside them received their pay, due to which the Military Pay Office was called to account by the Treasury. ${ }^{75}$ One year later, Lachowitz had already petitioned the Aulic War Council for his annual pay to be increased by 300 guilders. ${ }^{76}$

After a few years, without mention, Lachowitz's name appears in February 1697, in connection with a matter of inheritance. In a dispute between two heirs - a daughter and her stepmother - the determination of the placement of Turkish woman who had not yet been baptized was the issue. Lachowitz was asked to translate from German to Turkish during the swearing in and hearing of the Turkish woman in this matter. ${ }^{77}$

As in 1679, after the passage of nearly twenty years, Lachowitz's mother, Johanna Maximiliana (Guardi Damasin) Lachewitzin, turned to the Aulic War Council with a petition in September 1698, for his appointment to an important position: bitt ihren sohn, den Johann Adam Lechewitz, mit zu denen friedens tractaten zu schickhen und ihme den Dalman [Michael Talman] nicht vorgehen zu lassen. ${ }^{78}$ Talman must

68 Ibidem, Bd. 387. Exp. (1692) fol. 7r, fol. 80r.

69 Ibidem, fol. 7r.

70 Ibidem, fol. 43r.

71 Ibidem, fol. 193.

72 Ibidem, fol. 218.

73 ÖStA FHKA HF Bücher 1692. Bd. 991. fol. 194v (April 18, 1692), 296r (June 19, 1692); ibidem, HFÖ Akten 19. April 1692. Kt. 1482.

74 ÖStA FHKA HFU Akten 23. Dezember 1693. Kt. 821. Lachowitz's petition see: fol. 351.

75 Letter of the Aulic Chamber, November 16, 1693 see: ibidem, fol. 352. The report of the Aulic War Councile concerning the arrears to Lachowitz see: ibidem, fol. 351r.

76 ÖStA KA HKR Prot. Bd. 393. Exp. (1694) fol. 583.

77 Ibidem, Bd. 399. Exp. (1697) fol. 71.

78 Ibidem, Bd. 403. Exp. (1698) fol. 626r. Talman also petitioned them to order him to the peace negotiations. The role of Lachowitz's mother in the matter has also been noted by Dóra Kerekes. D. Kerekes, "A császári tolmácsok," p. 1223, note 182. 
have been much younger than Lachowitz, since he was brought in as an interpreter 12 years later than him, in $1691 .{ }^{79}$ However, either he proved to be more promising or he had more influential supporters at the court, and therefore Lachowitz had to utilize the influence of his mother. According to the decision of the War Council communicated on September 25, they ordered two Turkish interpreters to the peace negotiations at Karlowitz, Lachowitz and Talman. ${ }^{80}$ The two members of the imperial delegation at the peace negotiations in Karlowitz with ministerial rank were Count Wolfgang Oettingen-Wallerstein (1629-1708) and Count Leopold Anton Joseph Schlick (1663-1723), and the Imperial Colonel, geographer and cartographer, Count Luigi Ferdinando Marsigli also was given a place in the delegation. ${ }^{81}$

Lachowitz - on the basis of his own recollections - arrived in Karlowitz on October 14, 1698. When he was ordered to the negotiations, he was accompanying the main imperial army led by Prince Eugene of Savoy (1663-1736), which was already preparing for winter quarters and the interpreter was not prepared for the approaching cold weather. Thus, he subsequently had to petition for proper equipment and money to be sent after him because he only would have been able to acquire the necessary gear at Pétervárad at double the cost. ${ }^{82}$ Michael Talman, who was ordered to the negotiations, received 300 Rhenish guilders for equipment and travelling expenses, and they resolved to allocate him 5 Rhenish guilders per day, or 150 per month, for the provisioning of himself, his servant and his horse. However, in Lachowitz's case, the financial arrangements were more problematic in the calculation of his allowance, since he had already travelled from the theatre of war to the site of the negotiations. In Vienna, it was considered troublesome that he receives the same amount of money as Talman, since he did not have to travel from Vienna, and they thought that he must have already purchased a portion of the necessary apparel. Therefore, they wanted to pay him less money, 200 Rhenish guilders instead of $300 .{ }^{83}$

The examination of Lachowitz's presence and activity at the Karlowitz peace negotiations is also quite interesting, since his name comes up only sporadically or not at all in the later technical literature dealing with the signing of the treaty. When the interpreter on the Habsburg side is mentioned, it is essentially always the name Michael Talman that appears. ${ }^{84}$ This is despite the fact that in the journal of the imperial commissariat officer Johann Caspar Anton Hammerschmid, Lachowitz is mentioned

79 ÖStA KA HKR Prot. Bd. 386/1. Reg. (1691) 396v; D. Kerekes, “A császári tolmácsok,” p. 1226.

0 ÖStA KA HKR Prot. Bd. 404. Reg. (1698) fol. 399v.

81 L. Szita, G. Seewann, A karlócai béke, p. XXXVII.

82 ÖStA FHKA HFU Akten 5. Oktober 1699. Kt. 909. fol. 339.

83 Ibidem, Akten 20. Januar 1699. Kt. 898. fol. 338r, 342.

${ }^{84}$ Seewann mentioned Talman, who was ordered to the delegation, as an experienced interpreter, but not Lachowitz. L. Szita, G. Seewann, A karlócai béke, p. XXXVII. Cf. O. Klopp, Das Jahr 1683 und der folgende große Türkenkrieg bis zum Frieden von Carlowitz 1699, Graz 1882, p. 520. HammerPurgstall did not make mention of Lachowitz either, only Talman. J. Ha mmer-Purg sta1l, Geschichte des Osmanischen Reichs, vol. 6, Pest 1830, p. 656. Cf. I. Acsády, A karloviczi béke története, 1699, Budapest 1899 (Értekezések a történelmi tudományok köréböl, 18.), where Lachowitz does not appear either. 
as the first interpreter, as he is in the record book of the War Council, ${ }^{85}$ and his widow mentioned this in the petition submitted for his annuity. ${ }^{86}$ The reason for his name be pushed to the background may have been due to the fact that later Talman had a more significant career. In 1703, he became delegation secretary in Constantinople, and then obtained the post of resident in 1704, and was in office until 1714 and between 1716 and 1718, and he also participated in the negotiations for the treaty of Passarowitz as a military advisor. ${ }^{87}$ The work of the two interpreters at Karlowitz is hard to define, since in the surviving documentary materials about the negotiations there cannot really be found reports from them with their own signatures, they translated and acted as secretaries alongside the envoys. At the same time, it can be presumed that several of the reports sent to Vienna were prepared by the hand of Lachowitz.

Following the signing of the treaty, he presumably applied for the post of resident in Constantinople.$^{88} \mathrm{He}$ definitely did not receive this position, but he was ordered by the War Council along with the dragoman Leopold Mamucca della Torre ${ }^{89}$ (der orientalischen sprachen dollmätschen) to accompany the Habsburg delegation setting off for Constantinople led by Count Oettingen as secretary and interpreter (der secretario der orientalischen sparchen). ${ }^{90}$ Lachowitz himself in a submission in the year 1705, emphasized that he was ordered back from Kecskemét to Szalánkemén to assist in the exchange of ratifications there. ${ }^{11}$ In 1699, he was first allocated 1,000 Rhenish guilders, and then another 500 Rhenish guilders for his travelling expenses as a member of the delegation setting off for Constantinople..$^{92}$ The abbot of Neresheim, Simpert Niggl (1682-1706), who recorded Count Oettingen's journey to Constantinople that lasted from October 20, 1699 to January 29, 1701, mentioned Lachowitz's presence several times, noting about him: ein in disen [orientalischen] Sparchen und Landen sehr wohl erfahrner Mann (viz. "He is well up in these oriental languages and countries"). ${ }^{93}$ It is known from the abbot's description that Lachowitz rode in the

85 The travel journal of the imperial commissariat officer Johann Caspar Anton Hammerschmid from Vienna to Karlowitz, the site of the treaty. L. Szita, G. Seewann, A karlócai béke, p. 98.

86 ÖStA FHKA HFÖ Akten 12. Dezember 1710. Kt. 1902. Cf. the report of the Venetian envoy on the preparations for and proceedings of the Treaty of Karlowitz. L. Szita, G. Seewann, A karlócai béke, p. 199.

87 For Talman, see the citations in note 2.

88 On this question, for the time being I am only able to depend on the suggestion of Dóra Kerekes (D. Kerekes, "A császári tolmácsok,” p. 1223), because I have not yet found concrete data.

89 The son of Marc Antonio Mamucca della Torre, he served in Constantinople until the end of the war of re-conquest. D. Kerekes, Diplomaták, p. 102.

90 ÖStA KA HKR Prot. Bd. 407. Reg. (1699) fol. 247v, 249r, 322v; ÖStA FHKA HFU Akten 5. Oktober 1699. Kt. 909. For the mission to Constantinople of Count Wolfgang Öttingen (1629-1708), see: J. Hammer-Purgsta1l, Geschichte des Osmanischen Reiches, vol. 7, Pest 1831, pp. 16-28. At the same time, Talman was ordered to accompany the arriving Ottoman ambassadorial mission, see: ÖStA KA HKR Prot. Bd. 407. (1699) Reg. fol. 248r, 249v.

91 ÖStA FHKA HFÖ Akten 30. Oktober 1705. Kt. 1764.

92 ÖStA FHKA Hoffinanz Bücher Bd. 1019. fol. 606. (1699. 10. 05.). From July 1, 1703, his salary was 900 guilders, see: ibidem, HFÖ Akten 8. Februar 1704. Kt.1718. fol. 321.

93 S. Nigg1, Diarium oder ausführliche curiose Reiß-Beschreibung von Wien nach Constantinopel und von dar wieder zuruck in Teutschland, Augspurg 1701, p. 7. 
$15^{\text {th }}$ boat of the delegation with the Sprachknabes, ${ }^{94}$ and during the trip, outside Batina, Oettingen sent him ahead first to Pétervárad, to Dietrich Heinrich Nehem, to gain information about the spreading plague epidemic, and then to Belgrade to inquire about the arrival of the Ottoman ambassador. ${ }^{95}$ Later, from Büyükçekmece (Ponte Grande), he was again sent ahead to Constantinople for information, where he was received by the Reis ül-Küttab. ${ }^{96}$ Later, after the arrival of the delegation, Lachowitz again went to the Reis ül-Küttab to obtain an audience for the imperial envoy. ${ }^{97}$

\section{THE HABSBURG-OTTOMAN FRONTIER AT THE BEGINNING OF THE $18^{\text {TH }}$ CENTURY AND ITS LEGACY}

After the ambassadorial trip to Constantinople, one could meet up with the name of the secretary and interpreter Lachowitz only in connection with late payment of his salary. ${ }^{98}$ Presumably sometime around this time, in the first years of the century, he was able to attain the office of chief interpreter of the court, about the same time that Talman received the office of resident in Constantinople. ${ }^{99}$ In the autumn of 1707 , he was appointed as a commissioner of the delegation entrusted with the settlement of disputed issues along the frontier, subordinate to the Commander of Pétervárad, Nehem. On September 15, the Aulic War Council wrote to the Aulic Chamber that it should allocate money to Lachowitz for his living and travel expenses. The Chamber indicated on September 30 that they would be able to provide 300 Rhenish guilders per month. ${ }^{100}$ Again Lachowitz was able to make another step up in rank in his career when Joseph I (r. 1705-1711) named him imperial advisor on October 30, 1707. ${ }^{101}$

The creation of the Habsburg and the Ottoman boards of enquiry was necessary primarily due to the strike by Serbian military units against Kecskemét on April 3, 1707 , and the consequences of this. However, when the two delegations finally met in Szalánkemén on December 10, 1707, it came to light that the commissioner with full authority from the Sublime Porte was the difficile Elçi İbrahim, the Pasha of Belgrade

\footnotetext{
94 Ibidem, p. 13.

95 Ibidem, p. 34.

96 Ibidem, p. 114-115.

97 Ibidem, p. 121.

98 ÖStA FHKA HFÖ Akten 18. Februar 1707. Kt. 1799.
}

99 In 1704 Lacowitz is mentioned as the court interpreter. Cf. Zs. Barbarics-Hermanik, "İbrahim Müteferrika als transkultureller Vermittler im Osmanischen Reich" [in:] Frieden und Konfliktmanagement in interkulturellen Räumen. Das Osmanische Reich und die Habsburgermonarchie in der Frühen Neuzeit, eds. A. Strohmeyer, N. Spannenberger, Stuttgart 2013, p. 292, note 61.

100 ÖStA FHKA HFÖ Akten 3. Oktober 1707. Kt. 1815. Further data in connection with Lachowitz's allowance: ibidem, Akten 12. März 1708. Kt. 1825; ibidem, Akten 15. September 1708. Kt. 1839; ibidem, Akten 27. November 1708. Kt. 1844.

101 ÖStA FHKA Sammlungen und Selekte, Familienakten (SUS Fam. A.), L-2. fol. 11. 
(1707-1708), ${ }^{102}$ who was considered to be a hawk in the Ottoman government, and it was his intention to also include on the agenda the resolution of several disputed issues on the frontier that had stretched on for years, even making the discussion of the Kecskemét matter dependent on their satisfactory resolution. ${ }^{103}$ Therefore, the negotiations had to begin with the guard houses on the frontier as well as the matter of the two French ships attacked and appropriated by the imperial side at the port of Durazzo (present day Durrës in the Republic of Albania) back in $1704 .{ }^{104}$ The pasha, who certainly knew Lachowitz from the time of the Karlowitz negotiations and the exchange of envoys following it, ordered him to Belgrade several times during the negotiations to interrogate him personally, although during these times he was instead threatened and accused. In May and June of 1708 he held the secretary, who had again come to him, in captivity for several weeks, thereby forcing the commissioner on the imperial side, Commander Nehem, and the court in Vienna, to accept his conditions. ${ }^{105}$ Again the sources said nothing about the impression this impossible situation left on Lachowitz, and it is uncertain how well it was possible to prepare interpreters and commissioners for similar unexpected events, although at this time, they must have expected situations such as this due to their chosen profession. In any case, Nehem sent Lachowitz for a short time to Vienna following his captivity in Belgrade, but prior to the completion of the negotiations. ${ }^{106}$

Finally, the resolution of the Kecskemét matter took place during the reign of the new Pasha of Belgrade, Ali Pasha (1708-1710), ${ }^{107}$ in the spring of 1709. Arrears appeared in the payment due to Lachowitz in February, April and June of this year, ${ }^{108}$ and it is likely that this was not compensated by the fact that he received a gift from Ali Pasha as a conclusion to his work with the commission. ${ }^{109}$

102 For information on Elçi İbrahim pasha, see: H. Tóth, "Roma çasarıyla şevketlü padişahımuzun sulh $[\mathrm{u}]$ salah olub. The two Ali Pashas of Temeşvar on the Habsburg, Hungarian and Ottoman Frontier at the Time of the Rákóczi War of Independence" [in:] Şerefe. Studies in Honour of Prof. Géza Dávid on his seventieth Birthday, eds. P. Fodor, N.E. Kovács, B. Péri, Budapest 2019, p. 466, note 25, p. 473, note 59 .

103 For more detail on the issue, see: H. Tóth, "Török kereskedők..."

104 Michael Talman's report to the Aulic War Council. Constantinople, November 7, 1707. ÖStA HHStA Türkei I. Kt. 177. Konv. 3. fol. 177r. Cf. Zwischen Paschas, pp. 72-77. For more on the matter at Durazzo, see: J. Szabados, "Hírek...," pp. 96-97.

105 Zwischen Paschas, pp. 90-99. The agha wrote that Lachowitz was held for 20 days, but it is known that the secretary went to Belgrade on May 21 and was still there after a month had passed. Adam Johann Lachowitz's report to Dietrich Nehem, Belgrade, May 21, 1708, see: ÖStA HHStA Türkei I. Kt. 178. Konv. 2. fol. 61r-68v; Dietrich Nehem's report to the Aulic War Council, Pétervárad, June 26, 1708, see: ibidem, fol. $154 \mathrm{r}$.

106 The Aulic War Council to the Aulic Chamber to cover Lachowitz's expenses (he travelled to Vienna and back, and to the Ottomans). Attached is general Nehem's verification of June 18 about this, and about the fact that 900 guilders should be sent to the secretary, see: ÖStA FHKA HFU Akten 6. Juli 1708. Kt. 1011. fol. 59r-62v.

107 For information on Karayılanoğlu Ali Pasha, see: H. Tóth, Roma çasartyla, pp. 473-477.

108 ÖStA FHKA HFÖ Akten 7. Februar 1709. Kt. 1848; ibidem, Akten 17. April 1709. Kt. 1019. fol. 304r; ibidem, Akten 28. Juni 1709. Kt. 1020. fol. 346.

109 Which general Nehem considered very worrisome: Sonsten habe ich auch gehorsambst remonstrieret, das der pascha den herrn secretarius Lachawiz und hauptleutnant Castner als 
Lachowitz's wife, Polixenia Catharina von Lachowitz, was informed of her husband's death by the letter dated August 2, 1709, from the imperial chief engineer and Colonel Karl Dörck:

Ich bedaurn von grundt der seelen, daß ich denenselbten gehorsamst berichten mueß, welcher gestalten dero herr seelige den 31. Julii nach acht tägiger unpäßlichkheit, hauptsächlich aber an der lungensucht, zu Sulkoucze, zwey stundt von Possegga, geseegnet habe, welchen ich dan nacher Possegga beklaidet, und den 1. huius bey denen Jesuitten alda in die kürchen begraben lassen. ${ }^{110}$

The chief interpreter after an eight-day long sickness died of lung-disease (phthisis pulmonis) on July 31, close to Possegga (present day Požega in Croatia), when he travelled to another area of the frontier to fulfil an assignment that was both old and new, to examine the matter of the construction of guard houses in the Szerémség region and to make an agreement with the Ottoman officials. The widow had to face the fact that after her husband's long absence, he was buried in a foreign place far from his family. She was left with five children and following this had no other course of action than to bombard the War Council with petitions to receive an annuity to ensure their subsistence in consideration of her husband's more than thirty years of loyal and selfless service. Joseph I ordered on April 1, 1710, that the widow of the secretary Lachowitz should receive a yearly annuity of 600 guilders due to her husband's work. ${ }^{111}$

\section{SUMMARY}

Even the scanty source materials currently available provided us with an opportunity to gain insight into the life, key events and milestones of a Habsburg translator interpreter who had faded from memory. The factors that influenced and defined the development of Lachowitz's career can also be clearly perceived. During the examination, a pattern for official advancement also took shape, so it can be clearly seen how Lachowitz integrated or was able to fit into the official imperial system as well as how he advanced or was able to advance within this. Allowing for the fact that numerous factors were necessary for the realization of all this, his career can be considered typical. The fact that the young Lachowitz - to the extent that the source was not mistaken - had already applied for the position of chief interpreter at the end of 1685 shows that he was clear about the opportunities. However, it is difficult to judge what kind of expectations were placed on the quite dangerous duties he performed while serving in the following decades during the war against the Ottomans and on the frontier in terms of him gaining promotion. His career is made atypical by the fact that a significant portion of Lachowitz's official activities took place in the middle of

untercommissarien bey dem schluß ieden mit einem ausgerüsteten pferdt regaliert habe," Dietrich Nehem to the Aulic War Council, Pétervárad, May 5, 1709, see: ÖStA HHStA Türkei I. Kt. 178. Konv. 4. fol. 90r.

110 ÖStA FHKA HFÖ Akten 16. Mai 1710. Kt. 1884.

111 Ibidem. 
a major war, and furthermore that he performed them while actually accompanying the main imperial army during combat.

The exploration of an individual career helps in better understanding the operation of the official system as well as the activities of the interpreters and diplomats. In addition to this, we also receive data to sketch out networks of relationships. Surveying Lachowitz's career, at every turn one happens upon the key eastern interpreters and diplomats of the era. Light is also cast upon how the world of diplomacy and the private sphere were interwoven. His wife Polixenia Catharina von Lachowitz, who was mentioned several times, was the sister of a well-known diplomat, Christoph Ignatius Edler von Quarient und Rall, and he hastened to the widow's aid in petitioning for the annuity for her deceased husband. ${ }^{112}$ Continuing on with the Quareint und Rall family, it is also worthwhile to note that the wife of the former resident in Constantinople, Georg Christoph von Kunitz, was also a woman of the Quarient family. Looking at Lachowitz's ancestors, we currently know little about his father, but he definitely belonged to the official courtly class. Gotthart Carl Lachowitz was a geheimer österreichischer hoffkanzellist (viz. "secret Austrian court scribe"). ${ }^{113}$ Alongside him, Lachowitz's mother, who smoothed the path for her son's career as one could see above, also understood relationships in the court quite well, and in the sources she is referred to as Johanna Maximiliana Guardi Damasin Lachewitzin. I consider it conceivable that the term Guardi Damasin in her name or alongside her name - since in the registry of the War Council the family names were placed on the margins of the remarks - in reality was not a part of her proper name, but instead means a kind of Hofdamen (Eng. 'court ladies'), Guardadamas, ${ }^{114}$ and suggests that his mother was a maid of honour. This would make it more understandable that she would have played a crucial role in the advancement of her son.

Lachowitz left five children behind, and on the basis of the above it can be justifiably presumed that his children will surface as members of the imperial military and official system during further research stretching to the middle of the $18^{\text {th }}$ century. Until then, it is also possible to read the book entitled Paraemiae Lokmani sapientis ("Stories of Wise Lokman"), which has survived as an example of Lachowitz's intellectual legacy. The volume was published by Podestà in 1703 with the collaboration of Lachowitz. ${ }^{115}$ They intended for it to be used by students of eastern languages, as the stories can be read in Arabic, Persian and Ottoman Turkish accompanied by Latin translations.

112 Christoph Ignatius Edler von Quarient und Rall. Three versions of Quarient's petition have survived in the archival materials. Two of them only include the amount of money he requested for himself, while the third one includes the money requested by his sister as well. Ibidem.

113 ÖStA FHKA SUS Fam. A. L-2. fol. 9r.

114 Cf. K. Keller, Hofdamen. Amtsträgerinnen im Wiener Hofstaat des 17. Jahrhundert, WienKöln-Weimar 2005, passim.

115 Paraemiae Locmani sapientis ex Grammatica arabica clarissimi viri Thomae Erpenii expensis Johannis Baptistae Podesta, Constantinopoli per literatum Peram persicè per literatum Turcam turcicè redditae cura perillustris ac doctissimi viri domini Joannis Adami Lacheuiz, Viennae 1703. 
The career of Johann Adam Lachowitz also draws attention to the fact that although they were not soldiers, the envoys, interpreters, commissioners, apprentices, messengers and correspondents of the court in Vienna often saw to their duties and served the Habsburg interests at the risk of their own lives. Through their work they contributed to the functioning of the diplomatic machinery of the court in Vienna, the Sublime Porte and the Habsburg-Hungarian-Ottoman frontier that was fundamental to the signing of peace treaties and the resolution of conflicts, thus comprising a strong support system for the Habsburg Monarchy.

\section{BIBLIOGRAPHY}

\section{Primary Sources}

Österreichisches Staatsarchiv (Vienna), Finanz- und Hofkammerarchiv, Hoffinanz Bücher.

Österreichisches Staatsarchiv (Vienna), Finanz- und Hofkammerarchiv, Hoffinanz Österreich, Akten.

Österreichisches Staatsarchiv (Vienna), Finanz- und Hofkammerarchiv, Hoffinanz Ungarn, Akten.

Österreichisches Staatsarchiv (Vienna), Finanz- und Hofkammerarchiv, Sammlungen und Selekte, Familienakten.

Österreichisches Staatsarchiv (Vienna), Haus-, Hof- und Staatsarchiv, Staatenabteilungen, Türkei I.

Österreichisches Staatsarchiv (Vienna), Kriegsarchiv, Hofkriegsrat Protocollbücher.

Zülfikar mükalemesi. Vienna, Österreichische Nationalbibliothek, H.O.90.

\section{Primary Sources Published}

"A budai várban örzött török rabok jegyzéke. 1686. október 25" [in:] Buda visszafoglalásának emlékezete, ed. F. Szakály, Budapest 1986, pp. 575-576.

Kerekes D., "Egy császári tolmács megfigyelései. Giorgio Cleronome magyarországi utazása 1664-ben”, Lymbus 2004, pp. 71-77.

Kerekes D., "Johann Christoph von Kindsberg konstantinápolyi császári követ hagyatéka 1678-ból", Lymbus 2003, pp. 151-179.

Kerekes D., "Frakcióharcok Bécsben a XVII. század végén”, Lymbus 2008, pp. 163-191.

Lotharingiai Károly hadinaplója Buda visszafoglalásáról, in press, transl. K. Mollay, Budapest 1686.

Niggl S., Diarium oder ausführliche curiose Reiß-Beschreibung von Wien nach Constantinopel und von dar wieder zuruck in Teutschland, Augspurg 1701.

Paraemiae Locmani sapientis ex Grammatica arabica clarissimi viri Thomae Erpenii expensis Johannis Baptistae Podesta, Constantinopoli per literatum Peram persicè per literatum Turcam turcicè redditae cura perillustris ac doctissimi viri domini Joannis Adami Lacheuiz, Viennae 1703.

Szabados J., "Michael Talman Konstantinápolyi Habsburg rezidens két jelentése az Udvari Haditanács részére (1705. július 25. és augusztus 13.)”, Fons 2013, no. 3, pp. 385-419. 
Szita L., Seewann G., A karlócai béke és Európa. Dokumentumok a karlócai béke történetéhez 1698/1699, Pécs 1999.

\section{Literature}

Ács P., "Bécsi és magyar renegátok mint szultáni tolmácsok: Mahmud és Murád" [in:] Tanulmányok Szakály Ferenc emlékére, eds. P. Fodor, G. Pálffy, I.Gy. Tóth, Budapest 2002, pp. 15-27.

Acsády I., A karloviczi béke története, 1699, Budapest 1899 (Értekezések a történelmi tudományok köréböl, 18).

Bánrévy Gy., “Az első intézkedések a visszafoglalt Budán 1686-ban”, Tanulmányok Budapest múltjából 1936, no. 5, pp. 242-270.

Barbarics-Hermanik Zs., "İbrahim Müteferrika als transkultureller Vermittler im Osmanischen Reich" [in:] Frieden und Konfliktmanagement in interkulturellen Räumen. Das Osmanische Reich und die Habsburgermonarchie in der Frühen Neuzeit, eds. A. Strohmeyer, N. Spannenberger, Stuttgart 2013, pp. 283-308.

Benaglia G., Außführliche Reiß-Beschreibung von Wien nach Constantinopel und wieder zurück in Teutschland, auch was sich Merckwürdiges dabey zugetragen: deß Hoch-Gebohrnen Grafen und Herrn, Herrn Albrecht Caprara etc. etc., welche er als Ihro Römisch-Keyserl. Maj. Extraordinari-Gesandter und Gevollmächtigter den Stillstand mit der Ottomannis Pforten zu verlängern, verrichtet, Franckfurt 1687.

Biografia universale antica e moderna, vol. 36, Venezia 1827.

Cziráki Zs., "Habsburg-oszmán diplomácia a 17. század közepén: Simon Reniger konstantinápolyi Habsburg rezidens kinevezésének tanúságai (1647-1649)”, Századok 2015, no. 4, pp. 835-871.

Cziráki Zs., "Zur Person und Erwähnung des kaiserlichen Residenten in Konstantinopel, Simon Reniger von Renningen (1649-1666)" [in:] Wiener Archivforschungen: Festschrift für den ungarischen Archivdelegierten in Wien, István Fazekas, eds. Zs. Cziráki et al., Wien 2014, pp. 157-164.

Der Gefangene der Giauren. Die abenteuerlichen Schicksale des Dolmetschers Osman Ağa aus Temescwar, von ihm selbst erzählt, eds. R.F. Kreutel, O. Spies, Graz-Wien-Köln 1962.

Des Heil. Röm. Reichs Genealogisch-Historisches Adelslexicon, ed. J.F. Gauhen, Leipzig 1740.

Géra E. "Pillanatképek az ostrom utáni Budáról: török hadifoglyok, kincskeresők, szerencsevadászok", Fons 2016, no. 2, pp. 147-206.

Hammer-Purgstall J., Geschichte des Osmanischen Reichs, vol. 6-7, Pest 1830-1831.

Herczog J., “A Budán és Pesten fogságban lévő törökökről 1686. okt. 25-én készült jegyzék (1686)", Hadtörténelmi Közlemények 1916, pp. 434-435.

Hiller I., “A „Titkos Levelezők” intézménye” [in:] R. Várkonyi Ágnes Emlékkönyv, ed. P. Tusor, Budapest 1998, pp. 204-215.

Kármán G., Egy közép-európai odüsszeia a 17. században. Harsányi Nagy Jakab élete, Budapest 2013.

Kármán G., "Zülfikár aga portai fötolmács”, Aetas 2016, no. 3, pp. 54-76.

Károlyi Á., Buda és Pest visszavívása 1686-ban, Budapest 1886.

Keller K., Hofdamen. Amtsträgerinnen im Wiener Hofstaat des 17. Jahrhundert, WienKöln-Weimar 2005. 
Kerekes D., “A császári tolmácsok a magyarországi visszafoglaló háborúban”, Századok 2004, no. 5, pp. 1189-1228.

Kerekes D., “Az első „Keleti Nyelvek Kollégiuma” Bécsben. A császári tolmácsok képzése a 17. század végén" [in:] Österreichisch-ungarische Beziehungen auf dem Gebiet des Hochschulwesens, eds. Zs.K. Lengyel, J.Zs. Nagy, G. Újváry, Székesfehérvár-Budapest 2010, pp. 93-106.

Kerekes D., Diplomaták és kémek Konstantinápolyban, Budapest 2010.

Kerekes D., “Titkosszolgálat volt-e a Habsburgok 16-17. századi „Titkos Levelezői Hálózata"?" [in:] Kémek, ügynökök, besúgók. Az ókortól Mata Hariig. A szombathelyi Mediawave Fesztivál keretében 2011. június 3-án megrendezett tudományos konferencia elöadásai, ed. Cs. Katona, Szombathely 2014, pp. 97-136.

Klopp O., Das Jahr 1683 und der folgende große Türkenkrieg bis zum Frieden von Carlowitz 1699, Graz 1882.

Kovács Á., "Habsburg-oszmán diplomácia a harmincéves háború utolsó éveiben: Alexander Greiffenklau von Vollrats rezidensi tevékenysége" [in:] Paletta. II. koraújkor-történeti tudományos diákkonferencia, eds. D. Bódai, B. Vida, Volume of Essays, Budapest 2015, pp. 93-111.

F. Molnár M., Az Oszmán és a Habsburg Birodalom közötti határ kijelölése a karlócai békét követöen (1699-1701), PhD dissertation, Doctoral School of History, Faculty of Humanities, Eötvös Loránd University, Budapest 2008 (Page numbers according to the pdf document, see: http://doktori.btk.elte.hu/hist/fmolnar/phdmolnar.pdf [accessed: August 18, 2018]).

Papp S., “A Képes Krónika, Thuróczy János krónikája és a Tárih-i Üngürüsz kapcsolata. Volt-e „török fogságban” a Képes Krónika?” [in:] Szent Márton és Benedek nyomában. Tanulmányok Koszta László emlékére, Fontes et Libri 3, eds. T. Fedeles Tamás, Zs. Hunyadi, Szeged-Debrecen 2019, pp. 342-357.

Papp S., "Egy Habsburg-követ, Simon Reniger oszmán kapcsolathálózata Konstantinápolyban. Vezírek, muftik, magyar renegátok", Aetas 2016, no. 3, pp. 40-53.

Rothman E.N., Between Venice and Istanbul. Trans-Imperial Subjects and Cultural Mediation In The Early Modern Mediterranean. PhD dissertation, University of Michigan, Ann Arbor 2006 (https://utsc.utoronto.ca/ rothman/RothmanDiss.pdf [accessed: August 10, 2018]).

Spuler B., "Die europäische Diplomatie in Konstantinopel bis zum Frieden von Belgrad (1739)," vol. 3, Jahrbücher für Kultur und Geschichte der Slaven 1935, pp. 313-366.

Szabados J., “A 17. századi Habsburg-hírszerzés ,gyöngyszeme”. Hans Caspar budai titkos levelező (1646-1659) munkássága. Vázlat egy nagyobb összefoglaláshoz”, Aetas 2016, no. 3, pp. 77-92.

Szabados J., "Habsburg-oszmán kommunikáció a 17. század derekán. Johann Dietz császári futár halálának körülményei és következményei” [in:] Szóra bírni az újkort. A III. KoraújkorÁSZ doktorandusz konferencia tanulmányai, eds. T. Bodnár-Király, F. Hende, K. Pataki, Budapest 2016, pp. 192-216.

Szabados J., "Hírek Konstantinápolyból 1705 derekán. A nagypolitika történései egy Habsburg diplomata szemüvegén keresztül”, Hadtörténelmi Közlemények 2015, no. 1, 74-104.

Szabados J., „Ih awer befleise mih, daß ih sie beidte zue nahbarn mahen khan.” - Die Karriere des deutschen Renegaten (Hans Caspar) in Ofen (1627-1660) im politischen und kulturellen Kontext, $\mathrm{PhD}$ dissertation, Doctoral School of History, Faculty of Humanities and Social Sciences, University of Szeged, Szeged 2018. (doktori.bibl.u-szeged. hu/10058/1/Disszertáció_I kötet_Szabados János.pdf [accessed: February 7, 2018]).

The General Biographical Dictionary Containing an Historical and Critical Account, ed. A. Chalmers, vol. 22, London 1815. 
Torma K., A 18. századi végi-19. század elejei európai Hâfez-fordítások, PhD dissertation, Doctoral School of Literary Studies, Faculty of Humanities, Eötvös Loránd University, Budapest 2013. (http://doktori.btk.elte.hu/lit/tormakatalin/diss.pdf [accessed: July 5, 2018]).

Tóth H., A Kanizsával szembeni végvidék Gyöngyösi Nagy Ferenc levelezése tükrében (1683-1690), Szeged 2013.

Tóth H., "Roma çasarıyla şevketlü padişahımuzun sulh [u] salah olub. The two Ali Pashas of Temeşvar on the Habsburg, Hungarian and Ottoman Frontier at the Time of the Rákóczi War of Independence" [in:] Şerefe. Studies in Honour of Prof. Géza Dávid on his seventieth Birthday, eds. P. Fodor, N.E. Kovács, B. Péri, Budapest 2019, pp. 459-479.

Tóth H., "Török kereskedők nehézségei a kuruc korban - avagy hogy ne kereskedjünk Magyarországon a Rákóczi-szabadságharc idején", Acta Historica 2018, pp. 87-106.

Universal Lexikon der Gegenwart und Vergangenheit oder neuestes encyclopädisches Wörterbuch der Wissenschaften, Künste und Gewerbe, ed. H.A. Pierer, Altenburg 1843.

Zwischen Paschas und Generälen. Bericht des Osman Ă̆a aus Temeschwar über die Höhepunkte seines Wirkens als Diwansdolmetscher und Diplomat, eds. F. Kornauth, R.F. Kreutel, Graz-Wien-Köln 1966. 